that he was impatient of the slower reasoning processes of less gifted men. A man who is thus equipped mentally is always ahead of his time, and can only be properly appreciated by kindred spirits.

In so brief a summary one can give only an inadequate idea of the content and quality of Hopkins' autobiography. The story is packed with facts about the development of business on the Coast, largely of the kind that are not recorded in more formal and less personal records. Here the business man is seen at work, eagerly, almost frantically, seeking profit in an unstable and chaotic situation. Here are seen plans and schemes, honesty and dishonesty, success and failure. The picture is painted with the high color of strong feeling and subjective vision. Though such material must be used with care, it should be treasured for its quality of reality. Without that quality business history is at best lifeless and unreal.

Evelyn H. Puffer,

Harvard University.

\title{
Business and Capitalism
}

During the month of June the Society will send to its members Business and Capitalism by Professor N. S. B. Gras. The Society is most fortunate in being able to make this presentation, for the volume is of timely significance and genuine originality. Those who have read it are convinced that it will constitute an important landmark in the literature of business and economic history. It fills a long-felt need for a broad and realistic frame of reference for modern business enterprise. Rejecting the Marxian theory of capitalism as a phase of economic development which must yield to triumphant Socialism, Gras develops a challenging thesis :

A study of the history of capitalism shows that major struggles do not occur between capitalism and some other order of society but between two rival forms of capitalism. If any social group wishes to win in the social-economic contest, it must teach itself how to use capital and how to make capital flow in its direction. One group of capitalists may win over another and the victory may be progressive or retrogressive, but some form of capitalism will remain triumphant.

Original in concept and treatment, this book has as its object to explain the basic structure, policies, and services of business in its various stages. Its critical analysis of the growth, the functions, and the interaction of various types of capitalism should give a more nearly true perspective on business of today. 